\title{
ECOLOGICAL EFFECTS OF PESTICIDES CONTAMINATION ON AMPHIBIAN TADPOLES (Ptychadena bibroni) OF THE NIGER DELTA OF NIGERIA
}

\author{
Efeitos ecológicos da contaminação por pesticidas em girinos \\ de anfíbios (Ptychadena bibroni) no delta do Rio \\ Niger na Nigéria
}

Lawrence Ezemonye ${ }^{l}$

Isioma Ilechie ${ }^{2}$

\begin{abstract}
Ecological effects of pesticides contamination on amphibian larval stages were assessed using acute toxicity in the laboratory. The study compared the toxicity of two widely used pesticides, Atrazine (herbicide) and Basudin (insecticide) on the larval stages of dominant frogs Ptychadena bibroni of Niger Delta of Nigeria. The American society of Testing and Material (ASTM) recommended semi-static renewal bioassay was employed, and $\mathrm{LC}_{50}$ was measured at 96 hours. Mean estimated 96 hours $\mathrm{LC}_{50}$ values showed that Basudin $\left(\mathrm{LC}_{50}-0.860 \mu \mathrm{g} / \mathrm{l}\right)$ was more toxic than Atrazine $\left(\mathrm{LC}_{50} 230.62 \mu \mathrm{g} / \mathrm{l}\right)$. Derived $\mathrm{LC}_{50}$ values decreased with increased in exposure duration. Substantial mortality and incidences of abnormal avoidance response occurred more at higher concentrations. The high sensitivity of 14 days old test organism to both pesticides provides a rational for regulatory surveillance and monitoring of the waters of the Niger Delta ecological zone. The result obtained is an indication of early warning signs of possible depletion of the amphibian population from pesticides contamination in the Niger Delta ecological Zones of Nigeria.
\end{abstract}

Keywords: Acute toxicity; Amphibian; Ptychadena bibroni; Pesticides; Niger delta.

Researchers from Department of Animal and Environmental Biology (AEB) University of Benin, Benin City, Nigeria. +23480 23353847,08050261609 .

2 Researchers from Department of Animal and Environmental Biology (AEB) University of Benin, Benin City, Nigeria. +23480 23353847,080 50261609. Corresponding Author: ezemslaw@yahoo.com, isquared27@yahoo.com 


\section{Resumo}

Os efeitos ecológicos da contaminação por pesticidas em anfíbios no estágio larval foram avaliados usandose toxicidade aguda em laboratório. O estudo comparou a toxicidade de dois pesticidas, Atrazine (herbicida) e Basudin (inseticida) sobre o estágio larval de sapos Ptychadena bibroni, comuns no delta do rio Niger, na Nigéria. Para aplicação de pesticidas, a sociedade Americana de Testes e Materiais (SATM) recomenda uma aplicação semi-estática para posterior verificação de atividade biológica, sendo a $\mathrm{CL}_{50}$ medida após 96 horas. Valores médios estimados da $\mathrm{CL}_{50}$ nas 96 horas mostraram que Basudin $\left(\mathrm{CL}_{50}-0,860 \mu \mathrm{g} / \mathrm{l}\right)$ era mais tóxico que Atrazine $\left(\mathrm{CL}_{50} 230,62 \mu \mathrm{g} / \mathrm{l}\right)$. Valores da $\mathrm{CL}_{50}$ diminuíram com o aumento da duração de exposição. A mortalidade e incidentes anormais ocorreram somente nas concentrações maiores. A alta sensibilidade das formas larvais de 14 dias dos anfíbios, para ambos os pesticidas, demonstra a capacidade bioindicadora desses organismos aquáticos, apontando assim para inspeções regulares e monitoramento das águas do delta do Niger. O resultado obtido é um alerta sobre o risco de uma possível diminuição da população de anfíbios, por contaminação de pesticidas, nas zonas ecológicas do delta do rio Niger, na Nigéria.

Palavras-chave: Toxicidade aguda; Ptychadena bibroni; Anfíbios; Pesticidas; Delta do Niger.

\section{Introduction}

The effect of pesticides such as organophosphates and various organochlorines on amphibian populations are a growing concern (1, 2, 3). Amphibian populations are declining worldwide, with $48 \%$ of rapidly declining species being threatened by processes other than habitat destruction $(4,5)$. These organisms get exposed to pesticides by many routes but perhaps the most likely route is agricultural runoff .Widespread pesticide use makes it increasingly likely that nontarget species like amphibians get exposed to pesticide contamination (6). While pesticides have the potential to affect many aquatic taxa, the impact on amphibians are of particular concern because of the apparent global decline of many species $(7$, 8 , 9). The list of possible causes of amphibian declines are numerous and pesticides have been implicated in at least some of these declines (10).

Although pesticides are used on a local scale, they are ubiquitous and spread regionally and globally. They have been found in bodies of frogs from areas where pesticide use has not occurred historically or in the past 25 years (11, 12, 13). Amphibians living with pesticides in their habitats exhibit physiological defects from these pesticides. Recent studies provide evidence that pesticide reduce hatching success, decrease size at metamorphosis, causes physiological stress, liver and kidney degeneration, teratogenic effects, paralysis, to mention a few $(14,15,16)$.

Many amphibians species are vulnerable to aquatic contamination because they experience aquatic and terrestrial stressors, play vital roles in comminutes, are sensitive to contaminants, complete their life cycles near fields where pesticides are applied and have vulnerable embryo and larval stage whose development coincides with pesticides application $(6,17)$. Most pesticides are applied to fields in the beginning of the rainy season which correlates with the time of the year that tadpoles of many amphibian species are developing in surface water (18) which can alter the timing of metamorphosis. If time-tometamorphose is delayed, tadpoles have greater chance of predation in the aquatic environment when terrestrial emergence is postponed (19).

Environmental contaminants that alter the time of metamorphosis could cause potential detrimental consequence in amphibian population and can affect amphibians directly or indirectly causing mortality (20). Examining responses of organisms to lethal concentration of chemical is a reliable measure of contaminant sensitivity (21). Typically this is accomplished using standard mean lethal concentration $\left(\mathrm{LC}_{50}\right.$ ) tests, allowing comparison of responses within and among species. However, determining sub lethal effects (e.g. Behavioral changes) of a chemical is equally valuable in assessing sensitivity and is a often more favorable endpoint than mortality (22).

The objective of this study is to compare the toxicity of two widely used pesticide, Atrazine a herbicide and Basudin an insecticide used mainly for the control of weeds (Atrazine) and insect pests (Basudin) in most rice, yam, and vegetable farms in Nigeria. The study attempts to determine the acute toxicity of these pesticides (Atrazine and Basudin) on larval stages of the dominant frog species Ptychadena bibroni of Niger Delta of Nigeria. The study will also serve as early warning signs of possible depletion of the amphibian population by pesticide contamination in the Niger Delta regional zones of Nigeria. 


\section{Materials and method}

\section{Collection of test organisms and acclimatization}

Eggs of the amphibian species Ptychadena bibroni were colleted from an inlet at Ikpoba River, an inland River in southern Nigeria. Hatching of eggs, rearing of tadpoles and testing were done in the post-graduate ecotoxicological research laboratory, at the department of Animal and Environmental Biology, University of Benin, Nigeria. After hatching, emerging larvae tadpoles were distributed into six $(22 \times 22 \mathrm{~cm})$ plastic tanks each containing 1 litre of dechlorinated tap water and were allowed to acclimatize for seven days. Tadpoles were fed ad-libitum daily with ground maize powder. Larvae were reared on a 10: $14 \mathrm{~h}$ light: dark cycle to mimic natural condition and room temperature were maintained at $30 \pm 2^{\circ} \mathrm{C}$ through out the duration of the experiment. Larvae were subjected to concentrations of both pesticides. 0, 200, 400, $600 \mu \mathrm{g} / 1$ (Atrazine) and 0, 0.1, 1, 10, 25 $\mu \mathrm{g} / \mathrm{l}$ (Basudin). Each treatment concentration contained 20 tadpoles each per container. Acute toxicity for both pesticides was done in replicate tanks.

\section{Pesticides}

The pesticides used for the 96-hour acute toxicity test were the Organochlorine, Atrazine (Atraforce, 80\% Top Atrazine) and the Organophosphate, Basudin. Both of these pesticides are commonly used on farms in Nigeria for the control of weeds (Atrazine) and soil insects (Basudin).

\section{Bioassay proc2edure}

Stock solutions of the required concentrations were prepared for both pesticides. Serial dilutions of 200, 400 and $600 \mu \mathrm{g} / \mathrm{l}$ for Atazine (20). and $0.1,1,10,25 \mu \mathrm{g} / 1$ for Basudin (23) were made. The semi-static renewal bioassay procedure started with a range finding test (24). This was used to determine the range of concentrations to be tested and approximate the range that would produce the desired $\mathrm{LC}_{50}$ effect for the different life stages. A new stock solution for Atrazine was made up every 3 days immediately before each water change because it has a minimum half-life of 48hours in water (25).

\section{Mortality rate}

Mortality was recorded at an interval of 24 hours over a period of 4 days (96- hours). Tadpoles were taken dead when they turned upside down and sank to the bottom of the tank or when their tail showed no form of movement even when prodded with a glass rod (26).

\section{Avoidance response}

Larval avoidance response was monitored in this study. Alternation in avoidance response could increase susceptibility to predation $(27,28)$ and proceed mortality (29). Avoidance response was assessed in-situ by gently prodding all individual larvae and gauging their response as normal when larvae swims away immediately or abnormal when there is a delayed, no response or impaired swimming ability. The avoidance response of larvae 3 hours after herbicide treatment was used for statistical analysis (30).

\section{Statistical analysis}

The susceptibility of the tadpoles to both pesticides was determined using the probit method of analysis (31) for median lethal concentration LC50 at 96 hours. Computations of confidence interval of mortality rate were also obtained from the probit analyses used to determine the LC50 (Probit software).The two-factor ANOVA (analysis of variance) in Microsoft Excel was used to test the variables at $\mathrm{P}<0.05$ level of significance. Multiple bar graphs were also used in this study for the pictorial representation of assessment endpoint.

\section{Results}

The results of the acute toxicity of tadpoles exposed to varying concentrations of Atrazine and Basudin pesticides are presented in Tables 1,2 and 5 and further illustrated in Figures 1 and 2. 


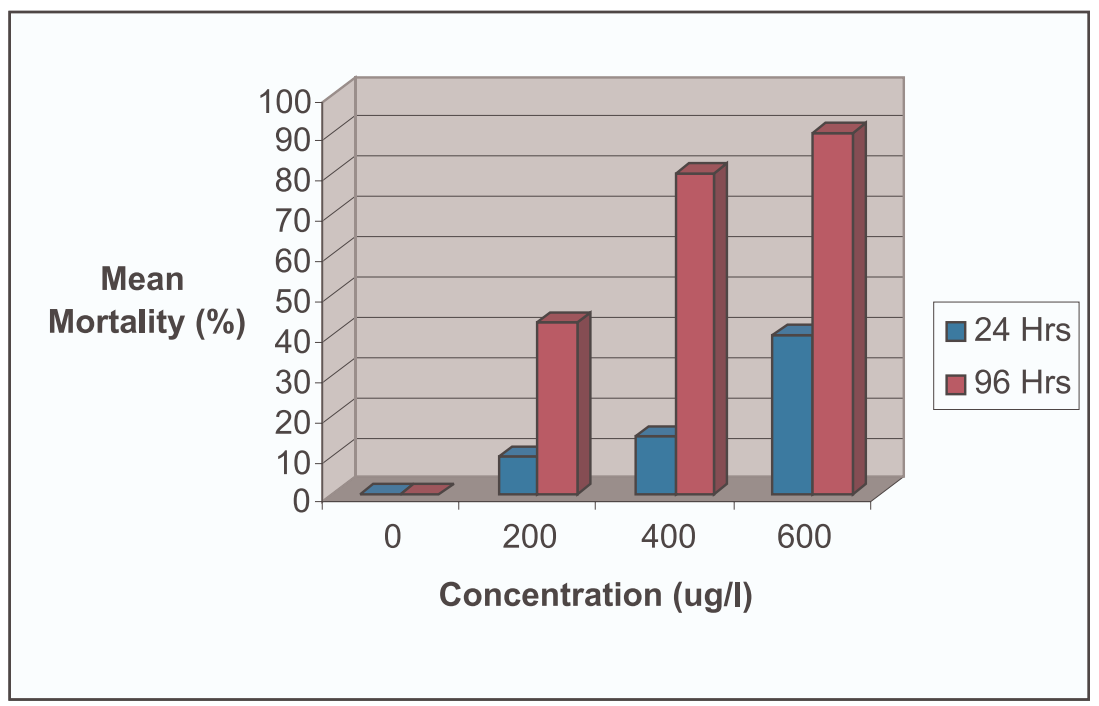

FIGURE 1 - Mean mortality of tadpoles exposed to different concentrations of Atrazine pesticide $(p<0.05)$

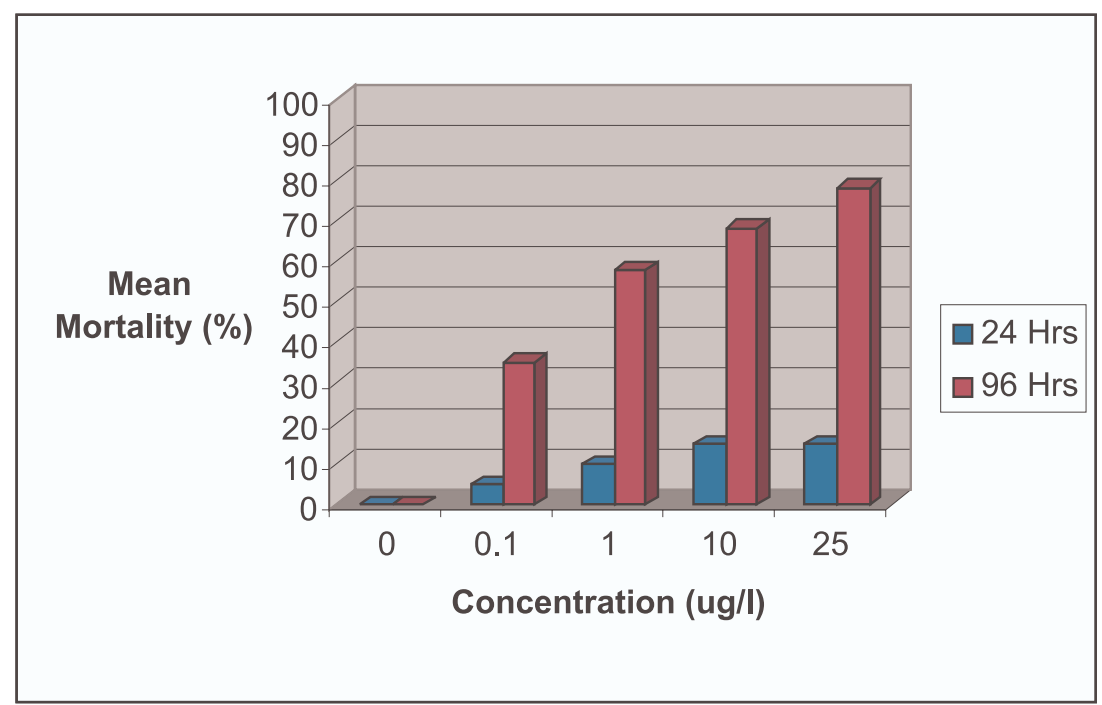

FIGURE 2 - Mean mortality of tadpoles exposed to different concentrations of Basudin pesticide $(p<0.05)$

\section{Control}

No mortality or morphological changes were observed in the controls for the 96-hour acute toxicity test. Tadpoles in the control experiment appeared active and healthy throughout the test period. The proportion of abnormal avoidance response in the control was less than $10 \%$.

\section{Atrazine exposure}

The test organisms exposed to varying Atrazine concentrations at 96- hrs recorded mortality in all the concentrations. The mean \% mortality for the 2 weeks old tadpoles of $P$. bibroni exposed to Atrazine were $43 \%, 80 \%$ and $90 \%$ for $200,400,600 \mu \mathrm{g} / \mathrm{l}$ concentrations respectively. This indicated that mortality increased with increased concentrations (Table 1 and 3; Figure 3). 
TABLE 1 - Mean mortality of tadpoles exposed to different concentrations of Atrazine pesticide (96-hours) $(p<0.05)$

\begin{tabular}{|c|c|cc|c|c|}
\hline \multirow{2}{*}{$\begin{array}{c}\text { Conc. } \\
(\boldsymbol{\mu g} / \mathbf{l})\end{array}$} & $\begin{array}{c}\text { Number } \\
\text { Tested }\end{array}$ & \multicolumn{2}{|c|}{ Number dead } & Mean & Mean \\
\cline { 3 - 5 } & & $\mathrm{X} 1$ & $\mathrm{X} 2$ & $\begin{array}{c}\text { Prortality } \\
\mathbf{( \% )}\end{array}$ & $\begin{array}{c}\text { Probit } \\
\text { value }\end{array}$ \\
\hline Control & 20 & 0 & 0 & 0 & 0 \\
200 & 20 & 9 & 8 & $43 \pm 0.71$ & 4.76 \\
400 & 20 & 16 & 16 & $80 \pm 0.00$ & 5.93 \\
600 & 20 & 19 & 17 & $90 \pm 1.23$ & 6.63 \\
\hline
\end{tabular}

TABLE 2 - Mean mortality of tadpoles exposed to different concentrations of Basudin pesticide (96-hours)

\begin{tabular}{|c|c|c|c|c|c|}
\hline \multirow{2}{*}{$\begin{array}{l}\text { Conc. } \\
(\mu \mathrm{g} / 1)\end{array}$} & \multirow{2}{*}{$\begin{array}{c}\text { Number } \\
\text { Tested }\end{array}$} & \multicolumn{2}{|c|}{ Number dead } & \multirow{2}{*}{$\begin{array}{c}\text { Mean } \\
\text { mortality } \\
(\%)\end{array}$} & \multirow{2}{*}{$\begin{array}{l}\text { Mean } \\
\text { Probit } \\
\text { value }\end{array}$} \\
\hline & & $\mathbf{X} 1$ & $\mathrm{X} 2$ & & \\
\hline Control & 20 & 0 & 0 & 0 & 0 \\
\hline 0.1 & 20 & 7 & 7 & $35 \pm 0$ & 4.63 \\
\hline 1.0 & 20 & 12 & 11 & $58 \pm 0.91$ & 5.03 \\
\hline 10.0 & 20 & 13 & 14 & $68 \pm 0.5$ & 5.42 \\
\hline 25 & 20 & 15 & 15 & $78 \pm 0$ & 5.58 \\
\hline
\end{tabular}

TABLE 3 - \% Abnormal advoidance reponse for Atrazine

\begin{tabular}{|c|c|cc|c|}
\hline Conc. $(\boldsymbol{\mu g} / \mathbf{l})$ & $\begin{array}{c}\text { Number } \\
\text { Tested }\end{array}$ & \multicolumn{2}{|c|}{$\begin{array}{c}\text { Abnormal avoidance } \\
\text { response }\end{array}$} & $\begin{array}{c}\text { Mean Abnormal avoidance } \\
\text { response (\%) }\end{array}$ \\
\cline { 3 - 4 } & & \multicolumn{2}{|c|}{ X1 } & X2 \\
\hline Control & 20 & 0 & 0 & 0 \\
200 & 20 & 7 & 8 & 38 \\
400 & 20 & 15 & 16 & 78 \\
600 & 20 & 19 & 17 & 90 \\
\hline
\end{tabular}


The concentrations also had varying degrees of behavioral alternations in the surviving tadpoles as observed in the avoidance response. The avoidance response was also concentration dependent. In the highest treatment concentration, many tadpoles displaying abnormal avoidance responses at approximately 3 hours post-treatment perished in subsequent days.

\section{Basudin exposure}

Mean \% mortality increased also with increased concentrations for Basudin pesticide exposure (Table 2 and 4; figure 4). The mean \% mortality were $35 \%, 58 \%, 68 \%, 75 \%$ for $0.1,1.0$, 10.0 and $25 \mu \mathrm{g} / 1$ concentrations respectively. Avoidance response was similar to Atrazine and was also concentration dependent.

TABLE 4 - \% Abnormal advoidance response for Basudin

\begin{tabular}{|c|c|cc|c|}
\hline Conc. $(\boldsymbol{\mu g} / \mathbf{1})$ & $\begin{array}{c}\text { Number } \\
\text { Tested }\end{array}$ & \multicolumn{2}{|c|}{$\begin{array}{c}\text { Abnormal avoidance } \\
\text { response }\end{array}$} & $\begin{array}{c}\text { Mean Abnormal avoidance } \\
\text { response (\%) }\end{array}$ \\
\cline { 2 - 3 } & & $\mathbf{X}$ X & \\
\hline Control & 20 & 0 & 0 & 0 \\
0.1 & 20 & 7 & 8 & 38 \\
1.0 & 20 & 12 & 16 & 70 \\
10.0 & 20 & 13 & 17 & 75 \\
25.0 & 20 & 15 & 19 & 85 \\
\hline
\end{tabular}

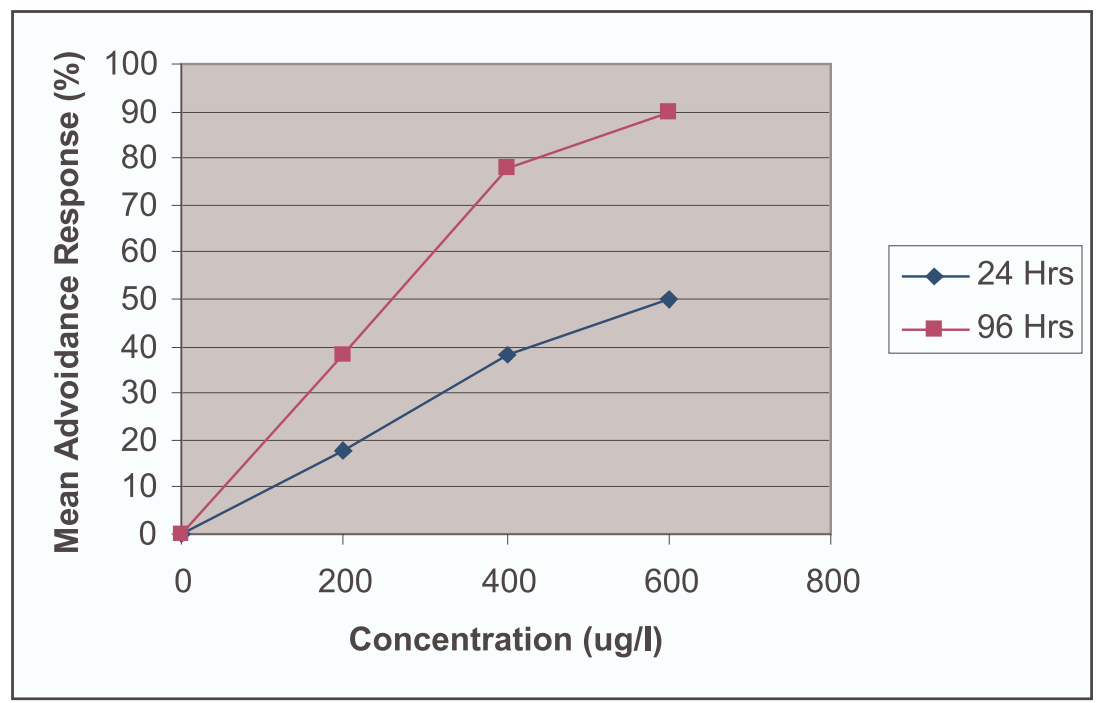

FIGURE 3 - \% Mean Abnormal Avoidance response for Atrazine $(p<0.05)$ 


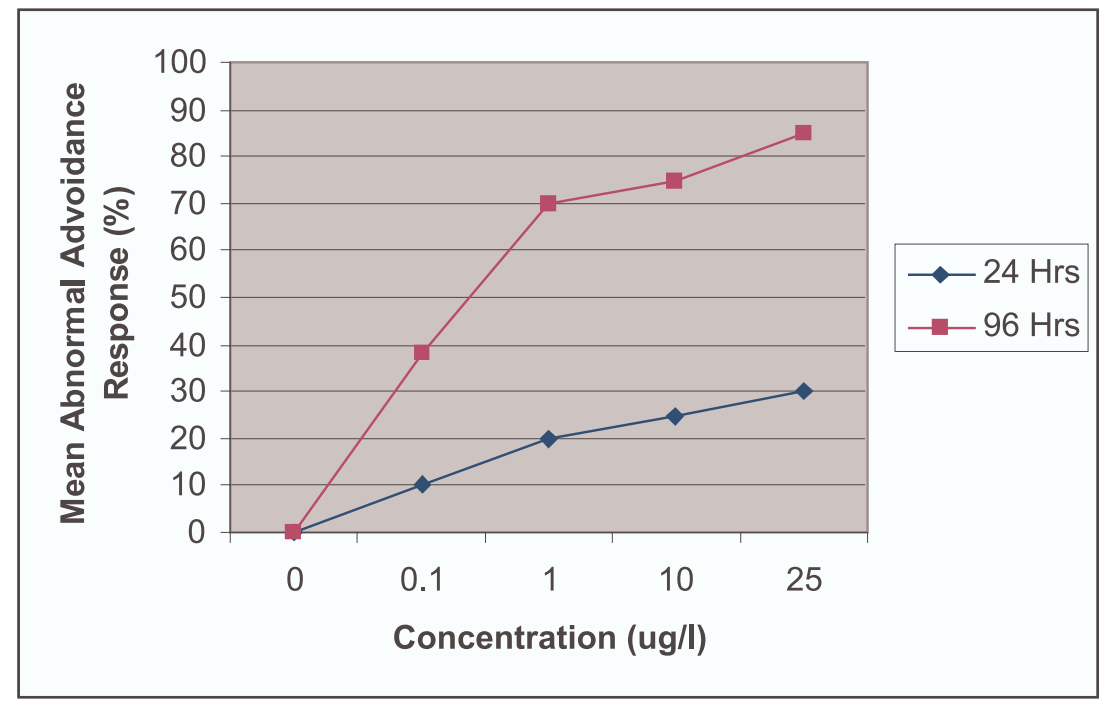

FIGURE 4 - Mean Abnormal Avoidance response for Basudin $(p<0,05)$

\section{Relative acute toxicity of atrazine and basudin pesticides}

On the basis of the derived 96-hrs $\mathrm{LC}_{50}$, Basudin $(0.860 \mu \mathrm{g} / 1)$ was found to be more toxic than Atrazine (230.621 $\mathrm{g} / 1)$ to tadpoles of $P$. bibroni. Derived $\mathrm{LC}_{50}$ values for $24,48,72$ hours followed a similar trend as described for 96 - hrs values of the test compounds (Table 5).

TABLE 5 - Mean LC50 Values of Atrazine and Basudin exposure at the end of 96-hours

\begin{tabular}{|c|c|c|c|c|c|}
\hline $\begin{array}{c}\text { Pesticide } \\
\text { treatment }\end{array}$ & $\begin{array}{c}\text { Time } \\
\mathbf{( H r s )}\end{array}$ & $\begin{array}{c}\mathbf{L C}_{\mathbf{5 0}} \mathbf{( 9 5 \%} \\
\mathbf{C L}) \boldsymbol{\mu g} / \mathbf{1}\end{array}$ & Probit Line equation & DF & Slope \\
\hline Atrazine & 96 Hours & $\begin{array}{c}230.621 \\
(148.7-\end{array}$ & $\mathrm{Y}=-4.264+3.920$ (LOGX Conc.) & 4 & 230.62 \\
& & $289.5)$ & & & \\
\hline Basudin & 96 Hours & $\begin{array}{c}0.860 \\
(0.010-\end{array}$ & $\mathrm{Y}=5.026+0.390$ (LOGX Conc.) & 6 & 0.860 \\
& & $5.098)$ & & & \\
\hline
\end{tabular}

\section{Discussion}

Until recently, the adverse effects of pesticides on non-target organisms have not been seriously considered in Nigeria, and toxicological studies with amphibians are relatively limited in number (32). Consequently, limited data on the toxicity of pesticides to amphibian larvae of $P$. bibroni are available for comparison with our results. The results of the experiment demonstrated that pesticides can have adverse direct (mortality) and indirect (physiological) effects on tadpoles.

Examination of our results indicates that both pesticides - Atrazine and Basudin varied greatly in their effects on survival and behaviour of $P$. bibroni. The highest mortality was found at 
the highest concentrations, suggesting dose dependent survival and concentration graded response. Basudin significantly induced mortality recording complete mortality at the highest treatment concentrations within 96 - hours while Atrazine had the least adverse lethal effects. Mortality rates were comparable to those reported for Rana pipiens and Rana clamitans exposed to similar concentrations of Basudin (23). Atrazine affected larval survival in this study but mortality was not as significant as for Basudin. Atrazine did not affect larval survival in gray tree frogs (33) Northern leopard frogs (34) and American toads (35). However, significant lower survival was reported in streamside salamanda (Amoystoma barbouri) and spring peepers ( $P$ seudacris crucifer, Bufo americanus Rana clamitans, Rana sylvatica) at low concentrations of $3 \mathrm{ppb}$ and $4 \mathrm{ppb}$ respectively $(36,37)$. At higher concentrations such as $200-600 \mu \mathrm{g} / \mathrm{l}$, Atrazine produced mortality on Xenopus laevis as reported by Freeman and Rayburn (20) and is consistent with our study.

The less sensitivity of $P$. bibroni to Atrazine may be due to species differences in susceptibility. $(38,35)$. Larval death occurred most rapidly in the highest concentration of Basudin indicating that short - term exposure to this concentration would be more detrimental to this amphibian species. The mortality of larvae could be explained by bioconcentration of these agrochemicals. Each of the two focal compounds in our study has been reported to bio concentrate in amphibian tadpoles $(34,39,40)$. This is an issue of serious ecological consequence. Larval mortality occurred more during exposure to high concentrations of Atrazine and Basudin than the controls, suggesting that death may have been due to the presence of the pesticides. Pesticide exposure induced abnormal avoidance response, skittishness and possible nervous system malfunction. Motor disorders in animals exposed to Atrazine and most organophosphate compounds like Basudin have been linked to their toxic effects in the Central Nervous System (35, 41). Most organophosphates like Basudin have been found to concentrate in tissues of frogs with depressed cholinesterase activity (42) and induce hyper activity in frogs followed by paralysis (35).

\section{Conclusion}

This study has unequivocally demonstrated that exposure of amphibian tadpoles to pesticides (Atrazine and Basudin) resulted in concentration dependent mortality and abnormal avoidance response. Atrazine (Herbicide) and Basudin (Insecticide) usage in the Nigerian Niger Delta is a common practice that often lead to the contamination of water bodies with pesticides through storm water runoffs. A sustainable biomonitoring program for pesticide contamination of the aquatic environment is advocative for the Niger Delta ecological zone. This program will enhance the protection of the observed amphibian decline in this sensitive ecological region of Nigeria.

\section{References}

1. Bishop CA. The effects of pesticides on amphibians and the implications for determining the causes of decline in amphibian population. In: Bishop CA, Pettit KE, editors. Decline in Canadian amphibian population: designing a natural monitoring strategy. Ottawa on: Canadian wildlife Service Occasional paper; 1992.

2. Hall RD, Henry PFP. Review Assessing effects of pesticides on amphibians and reptiles: Status and needs Herpetol J. 1992; 2:65-71

3. Phillips $\mathrm{K}$. Tracking the vanishing frog: an ecological mystery. New York: St. Martin's; 1994. 244 p.

4. Colborn T, Clement C. Chemically induced alternations in sexual and functional development: the wildlife human connection. Princeton NS: Princeton Scientific; 1992. 403 p.

5. Stuart SN, Chnason JS, Cox NA, Young BE, Rodrigues ASL, Fischman DL. Status and trends of amphibian declines and extinctions worldwide. Science. 2004; 306:1783-1786.

6. Blaustein AR, Kiesecker JM, Complexity in conservation: lessons from the decline of amphibian population. Ecol Lett. 2002; 5:597608. 
7. Blaustan AR, Wake DB. Declining amphibian populations: a global phenomenon? Trends in Ecology and Evolution. 1990; 5:203-204.

8. Alford RA, Richards SJ. Global amphibian declines: a problem in applied ecology. Annual Review of Ecology and Systematics. 1999; 30:133-165.

9. Holihan JE, Findlay CS, Schmidt BR, Meyers A.H, Kuzmin SL. Quantitative evidence for global amphibian population declines. Nature. 2001; 404:752-755.

10. McConnell LL, Le Noir JS, Datta S, Seiber JN. Wet deposition of current - use pesticides in the Sierra Nevada mountain range. California, USA: Environmental Toxicology and Chemistry. 1998; 17:1908-1916.

11. Datta S, Hansen L, McConnell L, Baker J, Le Nior J, Seiber JN. Pesticides contaminants in fish and tadpoles from the Kaweah River basin, California. Environ Contam Toxicol. 1998; 60:829-836.

12. Russell RW, Hecnar SJ Haffner GD. Organochlorine pesticides - residues in Ontario spring peepers. Environ Toxicol Chem. 1995; 14:815-817.

13. Russell RW, Gillan KA, Haffer GD. Polychlorinated biphenyls and chlorinated pesticides in southern Ontario, Canada, green frogs. Eviron Toxicol Chem. 1997; 16:2258-2263.

14. Smith GJ. Pesticides use and toxicology in relation to wildlife: organophosphate and carbamate compounds Washington DC. U.S. Department of the Interior, U.S. fish wildlife Service. Resource publication; 1987. $170 \mathrm{p}$.

15. Kamrin MA. Pesticides profiles toxicity, environmental impact, and fate. New York: Lewes; 1997. 676 p.

16. Power T, Clark KL, Harfenist A, Peakall DB. A review and evaluation of the amphibian toxicological literature. Ottawa, Ontario, Canada: Canadian wildlife Service. Technical Report (61); 1989. 222 p.

17. Heyes T, Haston K, Tsui M, Hoang A, Haefelle C, Vonk A. Atrazine induced hermorphropdism at $0.1 \mathrm{ppb}$ in American leopard frogs (Rana pipiens):late filed evidence. Environ Health Perspect. 2003; 111:568-575.
18. Rayburn AL, Norcott CA. Flow cytometric monitoring of aquatic ecosystems subjected to periodic flooding Illinous Groundwater Consorhum Research on Agricultural Chemicals in Illinois of Groundwater: Status and future Directions viii. Proceeding of Eight Annual conference; 1998 April 1-2; USA: Makanda, Il; 1998. p. 70-82.

19. Werner EE. Amphibian metamorphosis: Growth rate, predation risk, and the optimal size at transformation. Am Nat. 1986; 128:319-341.

20. Freeman JL, Rayburn AL. 2004 .Developmental impact of Atrazine on metamorphing Xenopus Laevis As revealed by nuclear analysis and morphology. Environmental Toxicology and Chemistry. 1986; 7 :1648-1653.

21. Bridges CM. Tadpoles swimming performance and activity affected by exposure to Sublethal levels of carbaryl. Arch Environ contain Toxicol. 1997; 16:1935-1939.

22. Little EE, Archeski RD, Flerov BA, Kozlovskaye VI. Behavioural indicators of sublethal toxicity in rainbow trout. Arch Environ. contain. Toxicol. 1990; 19:380-385.

23. Harris ML, Bishop CA, Strugers J, Ropley B, Bogart JP. The functional integrity of Northern leopard frog (Rana Pipiens) and Green forg (Rana Clamitans) populations in Orchard wetlands. 11. Effects life Pesticides and Eutrophic conditions on early life stage development Environmental Toxicology and Chemistry. 1998; 17:13511363.

24. American Society for Testing and materials. Standard practice for conducting acute toxicity test with fishes, macro invertebrates, and amphibians. In: Annual Book of ASTM standards. 1985; 11(4):272-296.

25. Solomon KR, Baker DB, Richard RP, Dixon DR, Ktaine SJ, Lapoint TW. Ecological risk assessment of Atrazine in North American surface waters. Environ Toxicol Chem. 1996; 15:31-74.

26. Mgbaeruhu JE. The influence of $\mathrm{pH}$ on the toxicity domestic detergents against tadpoles of Rana rana and fingerlings of Tilapia niloticus Msc thesis. University of Lagos; 2002. 67 p. 
27. Brodie ED, Formanowicz DR. Prey size preferences of predators: Differential vulunerability of larval amphibians. Herpetological. 1983; 39:67-75.

28. Cooke AS. Selective predation by newst on frog tadpoles treated with DDT. Nature. 1997; 229:275-276.

29. Kreutzweiser DP, Holmes SB, Eichenberg DC. Influences of exposure duration on the toxicology of triclopyr ester to fish and aquatic insects. Arch Environ contain Toxicol. 1994; 26:124-129.

30. Wojtaszek BF. In site investigation of the effects of vision and Realse silvicultural herbicides on plankton and larval amphibians. Canada: PhD Haesis, University of Guelph, Guelph; 2004.

31. Finney DJ. Probit Analysis. Cambridge, England, Canbridge: University press; 1971.

32. Ezemonye LIN, Enuneku A. Acute toxicity of cadmium to tadpoles of Bufo maculatus and Ptychedena Bibroni. Alfred Environ, Pollut. Health. 2005; 4(1):13-20.

33. Diana SG, Resetarits WJ, Schaeffer DJ, Beckmen KB, Beasley VR. Effects of Atrazine on amphibian growth and survival in artificial aquatic communities. Environ Toxicol Chem. 2000; 19:2961-2967.

34. Allran JW, Karasov WH. Effects of Atrazine on embryos, larva and adults of anuran amphibians. Environ Toxicol Chem. 2004; 20:769-775.

35. Berrill M, Coulson D, McgGllivray L, Pauli B. Toxicity of endosulfan to aquatic stages of anuan amphibians. Environ Toxicol Chem. 1998; 17:1738-1744.
36. Storrs SI, Kiesecker JM. Survivorship patterns of larval amphibians exposed to low concentrations of Atrazine. Environmental Health Perspectives. 2004; 112(101):1054-1057.

37. Rohr JR, Elskus AA, Shepherd BS, Crowley PH, McCarthy TM, Niedzwrecki JH, et al. Lethal and Sublethal effects of Atrazine, crabayl, endosulfan and octylphenn on the stream side salamander (Ambystoma barbouri). Environ Toxicol Chem. 2003; 226:2385-2392.

38. Semlitsch RD, Bridgesm CM, Welch AM. Genetic variation and a fitness trade off in the tolerance of gray treefrog (Hyla versicolor) tadpoles in the insecticide carbaryl. Oecologia. 2000; 125:179-185.

39. Naqui SM, Vaishnavi C. Bioaccumulative potential and toxicity of endosulfan insecticide to non target animals Comp Biochem Physiol C Pharmacol. Toxicol Endocrinol. 1993; 105:347361.

40. Ferreira Leach AMR, Hill EM. Bioconcentration and destruction of 4 Tert octylphenol residues in tissues of the rainbow trout (Oncorhychus mykiss). Mar Environ Res. 2001; 51:75-89.

41. Saglio P, Trijasse S. Behavourial responses to Atrazine and divron in goldfish. Arch Environ Contain Toxicol. 1998; 35: 484-391.

42. Sparling DW, Fellers GM, Mc Connell LL. pesticides and amphibian population declines in Calfornia, USA. Environ. Toxicol. Chem. 2001; 20:1591-1595.

Recebido/Received in: apr 28, 2006. Aceito/Accepted in: jun 30, 2006. 